\title{
TELEPÜLÉS- ÉS TERÜLETIDENTITÁS KIALAKÍTÁSA MARKETING ESZKÖZÖKKEL
}

\author{
(The creation of settlement and regional identity by marketing tools) \\ TÖRŐCSIK MÁRIA
}

A marketing irodalomban és gyakorlatban kiemelkedő jelentőségủ a Corporate Identity fogalmi kör, ami az egyes cégek megkülönböztetỏ jegyeit foglalja magában és a versenyképesség egyik előfeltételét jelenti.

Napjainkban a non-for-profit területeken is erösödik a verseny, föképp a forrásokért, a jó hírnév eléréséért, aminek sikeres megvalósitásához a koncepciózus marketing munka is jelentős mértékben hozzájárulhat.

A települések, területek identitása (Corporate Identity) azt jelenti, hogy világossá tehető és a célszemélyeknek egyértelmủen bizonyítható az a relatív versenyelöny, amivel az adott terület más területekkel össze nem téveszthető módon rendelkezik. Így érveket lehet ahhoz kapni, hogy miért éppen oda költöznek emberek, miért terveznek beruházásokat arra a településre, miért vonzó idegenforgalmi cél az adott térség stb.

A Corporate Identity átvitele térségekre azt feltételezi, hogy:

- képes legyen a település vagy a térség olyan kisugárzást adni, amivel a polgárok, vállalkozások, potenciális betelepülök, látogatók stb. azonosulni tudnak;

- a városvezetésben, térségfejlesztésben érzödjön a hitelesség; bizalom épülhessen ki a hosszabb távú tervek megvalósítása kapcsán;

- legyen ismert a település, a térség, vagyis alakuljanak ki pozitív beállítódások megfelelö marketing kommunikációval;

- legyen egyedülálló jellegzetesség, amit ki lehet hangsúlyozni, esetleg meg lehet teremteni marketing eszközökkel.

Világos tehát, hogy a térségek, a települések identitásának kialakítása stratégiai feladat. Olyan folyamatot feltételez, aminek eredmẻnye nem csupán a gazdaságban, hanem a polgárok közérzetében is megjelenik.

\section{A Corporate Identity lényege}

A különféle szervezetek, lehatárolható egységek (pl. település) esetében megfeleló célrendszert írhatunk le. Ezen célrendszer csúcsa az a filozófia, ami hosszú távra próbálja megfogalmazni egy egység legfontosabb törekvéseit (küldetés) és a megvalósitás magatartásbeli alapelveit (kultúra). A célhierarchia - marketingterületre koncentrált - felépítését az 1. ábra mutatja. 


\section{1. ÁBRA}

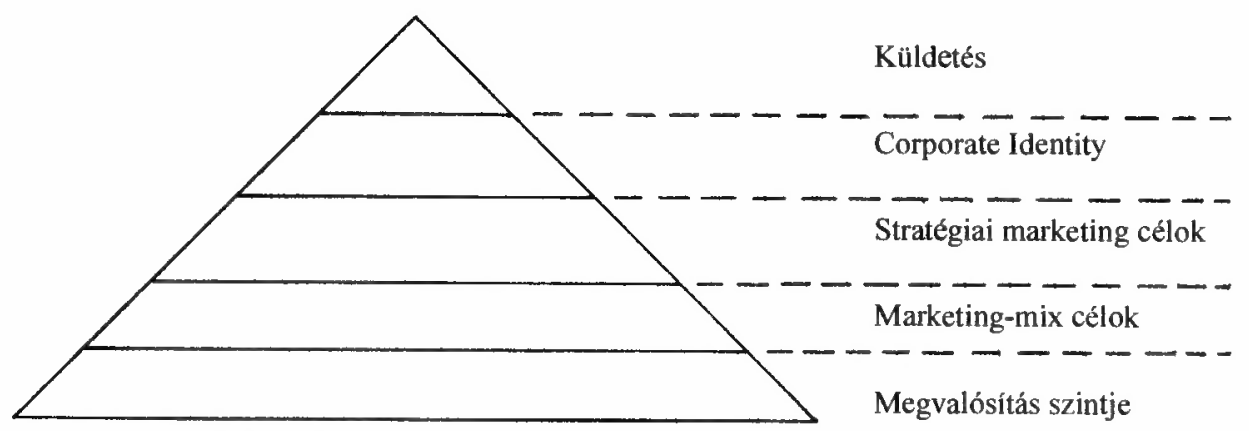

Szerkesztette: Töröcsik M.

Jelen gondolatsorunkban csupán a legfelső célokkal foglalkozunk, vagyis a küldetés megfogalmazása után föképp a Corporate Identity (a továbbiakban: CI) problémakörével.

Tulajdonképpen arról van szó, hogy a küldetés legfontosabb sarokkövének tisztázásával ezt (ezeket) láttatni is kívánjuk, vagyis a hosszú távon ható célokat, magatartásnormákat ủgy kell világossá tenni, hogy:

- mással össze nem hasonlitható hatásegyüttes jöjjön létre, illetve

- a különféle CI-elemek alkalmasak legyenek az azonositásra.

Mindezek után fogalmazzuk meg a CI alkotóelemeit és alkalmazásuk lehetóségét települések esetében.

\section{Corporate Identity}

A Corporate Identity egy cég ,személyiségét” jeleníti meg, ami a külsőségekböl, a viselkedésból és a kommunikációból kialakuló képet alkotja, vagyis

- a Corporate Design a vizuális, stabilizált megjelenési formát foglalja magában (írásmód, szimbólum, színek - adott cég grafikai rendszere),

- a Corporate Behavior a magatartást jelenti, amit adott cég munkatársai a velük kapcsolatban állók felé mutatnak,

- a Corporate Communication adott cég kommunikációi során kifejezésre juttatott stílusa szóban és írásban.

A CI tehát különféle területekböl összetevődő sajátos, adott cégre jellemző megjelenést eredményez, aminek a visszatükrözödése a Corporate Image, vagyis az a kép, ami az üzletfelekben, a tágabb környezetben él a cégről.

A jól átgondolt, egységes koncepció és annak kỏvetkezetes gyakorlati megvalósítása olyan karakteres vállalatképet eredményez, ami számtalan előnnyel jár: image-nyereség, a munkatársak motiváltságának növekedése, a piaci részesedés növekedése, forgalomnövekedés, új, kvalifikált munkatársak könnyebb megnyerése stb. 


\section{A települések CI-jének kiindulópontja}

A gazdaságban müködő szervezetekhez képest - ahol már bevált és elterjedt a CI koncepciózus alkalmazása - a települések speciális alakulatok, hiszen:

- a város nagy komplexitású területi, gazdasági és szociális rendszer, aminek a különbözỏ elemei, pl. kultúra, lakosság, infrastruktúra, területi elhelyezkedés stb. összefonódnak egymással;

- a döntési struktúra bonyolult, hiszen rendkivül heterogén érdekcsoportokat kell összhangba hozni (pl. pártok, egyesületek, lakócsoportok, vállalkozók stb., aminek megvalósítása, vagyis a konszenzus hosszú tárgyalások, csatározások eredménye;

- nehéz a célmeghatározás, hiszen az egyes részcélok egyaránt fontosak, mégis időnként prioritásokat kell meghatározni;

- a városokat számos téren törvény kötelezi bizonyos feladatok ellátására, vagyis nem lehet pl. csak ,vonzó” célokat kitüzni és teljesíteni;

- nem lehet csak az attraktiv szegmenseket kiválasztani, a cél-piacot számos "nehéz” csoport is alkotja, ami a hatékony müködést csorbithatja;

- a hosszú tóvú gondolkodás települések esetében 10-15 év is lehet, hiszen a városi identitás alapelemeit (pl. lakosság szerkezete, településszerkezet, városkép) nehéz - ha egyáltalán lehetséges - megváltoztatni.

\section{A marketing alapkérdése}

A hatékony CI-koncepció kialakitásához rendkivül fontos, hogy a relatív versenyelönyt meg tudjuk fogalmazni. A marketing alkalmazása ugyanis csak versenyhelyzetben nyer értelmet, vagyis akkor, ha pl. a beruházókat tơbb variáns, több telepítési cél mellett rá tudjuk venni, hogy nálunk fektessenek be, ha a kulönféle turisztikai célpontok közül a mi településünk lesz a legvonzóbb stb.

A marketing alapkérdése ezekben az esetekben az az egyszerünek tủnő néhány szó: „miért éppen engem válasszanak?". Értelmezve, miért válasszák a különféle célszegmensek a mi városunkat, mi az a vonzó és más benne, ami állja a versenyt más településekkel és relatív versenyelönyt jelent.

Az egyedi ,eladási" igéret, az a néhány szóval megfogalmazható és az identitás irányát megjelölö szlogen, ami egyedi, megismételhetetlen, a rendszer sajátosságát kifejezö összefoglaló.

Legjobban rögzíthetők a határozottan egy jellemzőt kiemeló és azt megfelelö kommunikációval megerỏsító tulajdonságok, pl. a legcsendesebb vidék, a legvonzóbb lankák stb.

Azt is megfogalmazhatjuk, hogy „személyiséget" kell adni a településnek, a térségnek ahhoz, hogy jól röpülhessen az érintettek fejébe, hogy létrejöhessen az az identitás, ami határozott vonzerőt gyakorol. 
Az egyedi ígéret, a megkülönböztetést célzó jelzők megfogalmazása nem egyszerü, hiszen a továbbiakban hosszú távon ezzel kell dolgozni, nem változtatható az aktuális céloknak megfelelöen.

A stratégiai koncepció tehát az alábbi követelményeknek kell, hogy megfeleljen:

- azonosulást kiváltó, vonzó cél legyen a CI alapja;

- hiteles legyen, hiszen a település, a térség tényleges adottságai nem mondhatnak ellent a beígértnek;

- bizalom kiépítésére legyen alkalmas, vagyis az igéreten túlmenően amit állítunk, az teljesüljön; lehessen bízni abban, amit állítunk;

- kompetencia fejeződjön ki;

- az egyedi, megkülönböztető sajátosság épüljön a település, a térség jellegzetességére.

A CI kiépítése tehát egy folyamatot feltételez, amelynek kiindulópontjaként meg kell határozni a város pozícióját és funkcióját az adott földrajzi, szociális és ökológiai környezetben, az ott élők érdekviszonyainak megfelelően.

\section{A település, a térség CI-elemei}

Mindezek alapján egy város Cl alapelemei a következőképpen írhatók le az általános, korábban rögzített összetevökhöz képest:

- a város-design magában foglalja a város és annak közvetlen környezete földrajzi elemeit (ezek rendkívül nehezen alakíthatók, inkább együtt kell élni velük, mintsem változtatásukra törekedni), épitészeti képét (fontosabb épületek, vonzó és rögzülö képi benyomások), a város szimbolikus önábrázolását (jelképek, zászló, elnevezés, színhasználat, betütípus-írásmód) vizuális eszközökkel;

- városkultúra, magatartásjellemzők, ami a város és a régió hagyományait, szokásait, valamint az önkormányzat, a hivatalok érintkezési jellemzóit tartalmazza a hozzáforduló polgárok és más célcsoportok esetében, és idetartozik a városban élö polgárok életfilozófiája, életszemlélete (kulturáltság, életstílus);

- városkommunikáció szóban és írásban, vagyis a közéleti tevékenység megnyilvánulásai, a különféle események, rendezvények (évfordulók, kiállítások, unnepségek), a városról készült írásos anyagok, tájékoztatók, prospektusok, médiahasználati eredmények.

Ha áttekintjük ezen elemeket, akkor látjuk, hogy egyik alkotórész nélkül sem lehet eredményt elérni, vagyis az együttes müködés, müködtetés adhat csak megfelelö összhatást. Gyakori probléma - nem csak nálunk -, hogy a város vezetői szívesen koncentrálnak egy-egy területre és rendkívül csalódottak, ha a várt hatást nem érik el. Leginkább azonban az jellemzi a gyakorlatot, hogy a Cl-elemek használata elôtt a koncepcióalkotás nem történik meg, a küldetés nem fogalmazódik meg, így az alkalmazott eszközök hatékonysága elenyésző. 
A települések, térségek CI-koncepciójának megvalósítása során arról végképp nem feledkezhetünk meg, hogy az ott élō embereknek a célokkal történö azonosulása nélkül nem érhetünk el eredményt. Hiába választjuk egyedi ígéretnek pl, a „legvendégszeretőbb vidék" szlogent, ha az ott lakók magukba zárkóznak és idegesek a turisták megjelenésekor.

Kiemelkedően fontos tehát, hogy a célrendszer meghatározásával az identitás kialakulását is elérjük. Ehhez a következỏ kritériumoknak kell megfelelni:

- individuális és szociális érzékenység fejeződjön ki a célok meghatározásában;

- az identitáshordozók kapcsolódjanak szorosan a térséghez;

- lássuk be, hogy ez egy heterogén és dinamikus folyamat, a kitủzött célhoz időnként kacskaringós út vezet;

- fontos a nagy nyilvánosság a megvalósításhoz, hiszen meg kell győzni a célcsoportokat és elfogadtatni velukk a (tölük nem távol álló) célokat;

- kölcsönhatásokra lehet számítani az elemek megvalósítása során, amely folyamat optimális esetben szinergiát hoz létre, vagyis jobb lesz az eredmény együttes hatása, mint amit az elemek külön-külön el tudnának érni;

- dialógus jellegú a folyamat, a különböző célcsoportok változtatnak is a megvalósítási módokon.

A különféle CI-akciók eredményeképpen létrejön a város- vagy település-image, ami a megtett intézkedések visszatükrözödése a célcsoportokban.

\section{CI-kutatások}

A Corporate Identity vizsgálatára vonatkozó kutatások közül kiemelünk egy 1990-ben Németországban lefolytatott felmérést. A kutatásba minden ötvenezer lakosnál nagyobb lélekszámú települést bevontak, a válaszadók aránya $57 \%$ volt. A kutatás legfontosabb megállapításai szerint a városokat foglalkoztatja a CI problémaköre:

- 21\%-uk már végzett kutatást ezen a területen;

- 17\%-uk megkezdett kutatásról számolt be;

- 17\%-uk tervezi ilyen kutatás indítását;

- 45\%-uk még nem gondolt rá.

A felmérésben részt vevők a városok legfontosabb feladatait az alábbiakban adták meg:

- a polgárok identitásának elösegitése;

- a bevásárlóhelyek erösítése;

- image-javítás;

- vállalkozások letelepítése;

- a város egységes önbemutatása;

- közelebb kerülés a polgárokhoz. 
Közepesen fontos feladatoknak minösülnek:

- a turizmus;

- a kongresszusi idegenforgalom;

- a polgári cselekvőkedv fokozása.

Kevéssé fontos feladatok:

- a városi alkalmazottak elégedettségének növelése;

- a városi kormányzatban a szervezés javitása;

- a vándorlási veszteség korlátozása;

- a városi intézmények jobb leterhelése.

A CI-projektek átlagos idötartama három év volt, a projektek súlypontját a design- és a kommunikáció-fejlesztés adta.

\section{Ajánlás}

Az ma már kézenfekvő megállapítás, hogy a marketing gondolkodást nem nélkülözhetik a települések, térségek vezetői. A klasszikus marketing ismeretek autentikus adaptálása elengedhetetlen, vagyis a sajátosságokat figyelembe véve koncepcionális gondolkodásra kell törekedni.

A legnagyobb veszélyt abban látom, hogy a vezetők jelentős része $a z$ egyes - leginkább a látványos - marketing eszközöket alkalmazza, de elötte nem végzi el a koncepcióalkotás folyamatát, pedig település-, térségfilozófia nélkül nem érhetổ el hosszú távú és megfelelö eredmény.

Nem lehet a koncepcióalkotást kikerülni, amennyiben enélkül dolgozunk, kidobjuk az ablakon a nehezen megszerzett pénzeket!

Nem lehet a CI-elemeket önmagukban alkalmazni, egy-egy elemet kiemelni, mert nem érjük el a kívánt hatást és egyben lemondunk a szinergiáról.

Rendkivül fontos egy reális helyzetelemzés elvégzése, aminek alapján

- pozicionálhatjuk a települést vagy a térséget és

- meghatározhatjuk a célcsoportokat.

Ne spóroljunk éppen a kutatásokon, melyek nagyságrendekkel kevesebbe kerülnek, mint pl. egy reklámkampány! A reális helyzetelemzést sokszor éppen a független szervezetek, személyek által végzett kutatások alapján végezhetjük el.

Minden (vagy minél több) érintett tudjon az elfogadott koncepcióról és lehetőség szerint minél többen támogassák is azt!

A marketing sem csodaszer. Eladni, jól és hosszú távon eladni csakis akkor lehet, ha az, amit kínálunk, elönyös, pozitív alapadottságokkal is rendelkezik. A hitelesség az identitás kialakulásának az alapja.

Úgy gondolom, egyre több jól képzett szakember, egyre több kutatóhely áll az érintettèk rendelkezésére, hogy támogatást kapjanak a nehéz és felelösségteljes döntések meghozatalában. Érdemes és szükséges a fontos célok elérése érdekében együttmüködnünk. 


\section{Irodalom}

Áts Zs. (1994) Önkormányzatok marketing-kommunikációja. Marketing, 1. 59-62. o.

Barakonyi K. - Lorange P. (1992) Stratégiai menedzsment. KMK.

Jacobs, S. (1991) Citymarketing. Marketing und Management, 2. 121-130. o

Lalli/Plöge (1991) Corporate Identity für Städte. Marketing und Management, 4. 237-248. o.

Németh M. (1991) Külkereskedelmi marketing kommunikáció I-Il. kötet. Külkereskedelmi Főiskola, Budapest. Rechnitzer J. (1993) Szétszakadás vagy felzárkózás. MTA RKK, Győr.

Sándor I. (1991) Marketingkommunikáció. BKI, Budapest.

Schmidt L. (1994) Önkormányzat és marketing. Marketing, 3. 168-172. o.

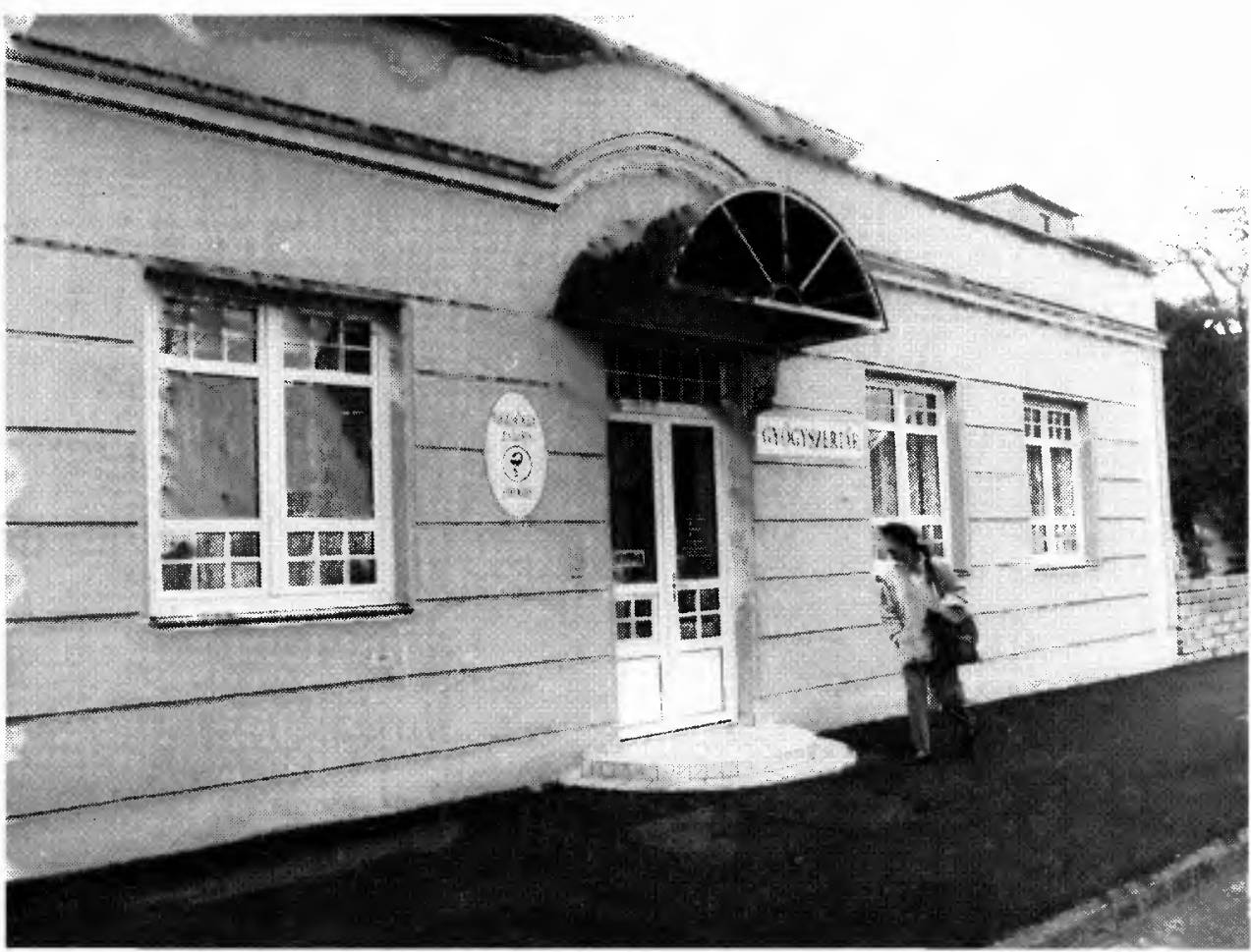

Az év patikảja a soproni Erzsébet magángyógyszertár

(MTI FOTÓ - Matusz Károly) 
Tér és Társadalom 9. évf. 1995/1-2. 24. p.

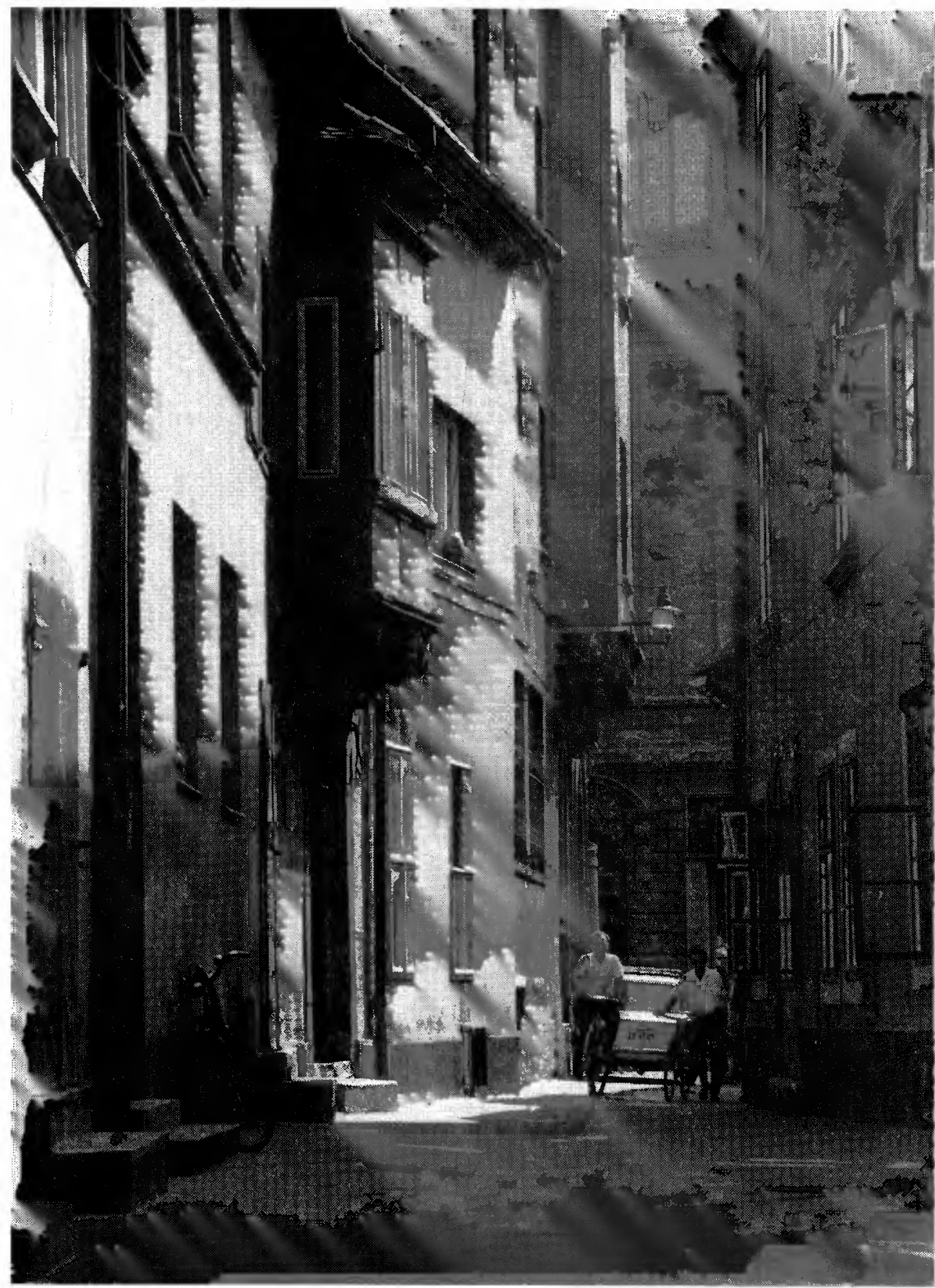

Győr régi arca-jellegzetes szük belvárosi utcarészlet (MTI FOTÓ - Hadas János) 